\title{
Meta
}

Journal des traducteurs

Translators' Journal

STRANIERo SERgio, Francesco and FALBo, Caterina (2012):

Breaking Ground in Corpus-Based Interpreting Studies. Bern/New York: Peter Lang International Academic Publishers, 254 p.

\section{Rongbo Fu}

Volume 59, numéro 3, décembre 2014

URI : https://id.erudit.org/iderudit/1028666ar

DOI : https://doi.org/10.7202/1028666ar

Aller au sommaire du numéro

Éditeur(s)

Les Presses de l’Université de Montréal

ISSN

0026-0452 (imprimé)

1492-1421 (numérique)

Découvrir la revue

Citer ce compte rendu

Fu, R. (2014). Compte rendu de [STRANIERo SERGio, Francesco and FALBo, Caterina (2012): Breaking Ground in Corpus-Based Interpreting Studies.

Bern/New York: Peter Lang International Academic Publishers, 254 p.] Meta,

59(3), 695-696. https://doi.org/10.7202/1028666ar d'utilisation que vous pouvez consulter en ligne.

https://apropos.erudit.org/fr/usagers/politique-dutilisation/ 
début de "présence professionnelle» et constitue un atout précieux dans sa formation.

AnneMarie Taravella Université de Sherbrooke, Sherbrooke, Canada

Straniero Sergio, Francesco and Falbo, Caterina (2012): Breaking Ground in CorpusBased Interpreting Studies. Bern/New York: Peter Lang International Academic Publishers, 254 p.

Interpreting studies as a recognized academic pursuit has only been in existence for some 60 years but has already witnessed a range of shifts in its research paradigm. The University of Trieste has been in the forefront of the more recent development of the discipline, serving as a catalyst for new and innovative efforts, including the first epochmaking interpreting symposium that triggered the cross-disciplinary approach, the publishing of The Interpreters' Newsletter - the first academic journal specializing in interpreting studies - and the introduction of the neuropsychological paradigm, among other things. All these clearly signal the ethos embraced by researchers from that institution, i.e., pioneering research in the field.

Their achievements have been further applauded in the recent book edited jointly by Francesco Straniero Sergio and Caterina Falbo, entitled Breaking Ground in Corpus-based Interpreting Studies. It highlights some fresh advancements and thoughts on building and using interpreting corpora. The book comprises eight chapters, starting with an overview of the field, followed by seven chapters featuring introductions to or case analyses of specific corpora.

In the first chapter, Straniero Sergio and Falbo focus on main issues and challenges concerning the development and application of interpreting corpora against the landscape of corpus-based translation studies. Since designing and creating interpreting corpora is the first step in sparking such studies, the chapter begins with a summary of five macro-factors the authors see as key to defining a truly representative interpreting corpus, namely, interpreter, situational content, mode, language and directionality, type of interaction. These parameters, as they claim, make it "possible to concentrate on a particular communicative situation" and "obtain results related to interpretation in that particular situation" (p.13). While corpora play a significant role in promoting traditional translation studies, their use in seeking translated features such as universals or laws generates little knowledge of extra-linguistic aspects of the activity other than some descriptive analyses of linguistic regularities; hence the appeal to "go beyond ... and look for cognitive, ethical, social, cultural and even ideological explanations outside translated texts" (p. 22). The authors feel this also holds true for corpus-based interpreting studies. Moreover, given the difficulties of data access and transcription in creating an interpreting corpus, they view the development of interpreting corpora as still in an embryonic stage and consider qualitative research to be more appropriate. The chapter concludes with a particular emphasis on data comparability which is seen as a strong determinant of research quality and validity.

The second chapter is a comprehensive introduction to the building, query and research topics of EPIC, a trilingual corpus comprising a total of nine sub-corpora of simultaneous interpretation in English, French and Spanish. Mariachiara Russo et al. examine in detail the methodology used to develop the corpus, including data collection, digitization, transcription, and annotation, etc. As the first interpreting corpus developed for research and pedagogical purposes globally, EPIC has served as an ideal testing ground for conventional hypotheses and beliefs. The authors note that research output related to EPIC deals mainly with such aspects as lexical density and variety, disfluencies, speed and mode of delivery. Interestingly, EPIC is also becoming a data source for many local M.A. dissertations, some of which are "especially innovative” (p. 78). With upgrading work such as corpus expansion and text/sound (video) alignment steadily underway, EPIC's research and teaching potential is clearly enormous.

In the third chapter Claudio Bendazzoli offers some inspiring reflections on data classification and annotation of DIRSI, a bilingual (Italian/ English) parallel interpreting corpus of international medical conferences whose development draws on EPIC's creation experience. However, as the DIRSI data source is not comparable to that of EPIC, fresh efforts in data processing are needed. To this end, the author views international conferences as communicative situations and presents some relevant conceptions regarding conference structure, speech events, participants, etc. that ultimately constitute a part of the header in DIRSI. The author's implied purpose is to gain greater insight into the situations of an interpretermediated event apart from studying interpreting merely as a process or a product.

In "Introducing FOOTIE: simultaneous interpreting in football press conferences," Annalisa Sandrelli initially presents a panoramic overview of football translation and interpreting - a peculiar area of the profession, ranging from industrial demand to interpreters' policy. The creation of FOOTIE immediately benefited from the staging of EURO 2008, a major European football 
competition where a range of press conferences were held. In terms of research potentials, the author sees FOOTIE as an ideal example of institutional interaction and, much like Bendazzoli in chapter three, she adopts an ethnographic approach to the processing of data, classifying them in different categories as per speech events and participants. The author finally sketches future steps needed to advance the development of the corpus and the research work.

Caterina Falbo's paper in the fifth chapter is an introduction to the CorIT (Italian Television Interpreting Corpus) and its classification criteria. CorIT is an inclusive database of interpretation carried out on Italian television over a span of nearly 50 years. Taking into consideration the complicated nature of television interpreting, the paper focuses extensively on a discussion of three controversial concepts in classifying data as such, i.e., interpreting mode, interaction types and television genres. In the end, Falbo rightly points out that CorIT boasts some unique research potentials in the sense that studies can examine not only "the interpreter's performance and behavior, but also the evolution of 'television-making' and its relevant linguistic practices” (p. 176).

The sixth chapter is Eugenia D. Fovo's description of her ongoing doctoral research project on question/answer coherence in television interpreting. The author begins with a review of her original work in her dissertation and identifies some major difficulties of conducting research on television interpreting with a corpus-based approach. She then moves on to the analysis of the main methodological problems in her previous endeavor and presents a thorough reflection on the selection of corpus and means of analysis. Her paper is thus methodologically awareness-raising for many corpus-based interpreting studies alike.

Chapter seven presents another attempt to exploit CorIT's research potentials. As the author Francesco Straniero Sergio correctly suggests at the start, CorIT differs from other interpretingbased corpora in terms of its "availability of a large number of simultaneous and/or consecutive interpretations delivered by the same interpreter over a period of 15-20 years" (p. 211); hence the possibility of discovering the stylistic features in interpreters' performances. To actualize the description of style of specific interpreters, the author proposes four indicators: lexical choices, language use, discourse markers and décalage (p. 213). Though seemingly boundless, they all prove to be quite effective in the detailed analysis that followed.

Marta Biagini devotes the last chapter to a discussion of corpora's role in promoting research on legal interpreting and some major challenges of developing corpora as such. While a corpus-based approach proves to be fruitful in research on dialogue interpreting, the author acknowledges that, after a review of the field, the present status quo is far from satisfactory. This obviously holds true for legal interpreting research in that few descriptive studies address issues as to "how and with what consequences interpreter-mediated interactions take place in the highly formal and ritualized institutional setting of the court" (p. 236). However, as the author suggests, answering these questions raises a host of data collection challenges involving practical and technical constraints such as permission to access data. The author thus draws on his experience of developing a French-Italian corpus of legal interpreting to present a full observation and comparison of different stages in data collection with their pros and cons.

As the first of its kind systematically devoted to corpus-based interpreting studies, the book is impressive in several respects. First, as regards the five corpora it introduces, each boasts a unique data source thereby enabling researchers to probe into the domain-specific discourse of interpreting. Second, fresh attempts are made to improve the existing corpora in terms of their size, multimodality, classification criteria, transcription method, and so on. Third, contributors take the initiative in going beyond perspectives and topics commonly adopted in corpus-based translational studies and shifting their research focus towards a socio-cultural dimension.

In sum, the present collection, though still limited in coverage of content, is a relatively comprehensive source towards understanding the state of the field and will give a strong impetus to the growth of corpus-based interpreting studies.

Rongbo Fu

Xiamen University, Xiamen, People's Republic of China

Simon, Sherry (2012): Cities in Translation: Intersections of Language and Memory. London and New York: Routledge, 2012, 204 p.

This book is about translation and "dual cities," those whose specificity lies "in the presence of two historically rooted language communities who feel a sense of entitlement to the same territory" (p. 3). Each of these cities has been a privileged place for cultural and linguistic exchange because of its prominent geographical location or its strategic relevance as a commercial or administrative centre or border town, in which difference is a native feature of the urban landscape. In her study of Calcutta (1800 to 1880), Trieste (1850 to 1918), Barcelona (1975 to 2000), and Montreal, (1940 to 2000), 